\title{
UMT Education Review (UER)
}

Volume No.1, Issue No. 2, 2018

蓑UER

ISSN: 2616-9738 (Print) 2616-9746 (Online)

Journal DOI: https://doi.org/10.32350/uer

Issue DOI: https://doi.org/10.32350/uer.12

Homepage: https://ssh.umt.edu.pk/uer/home.aspx

Journal QR Code:

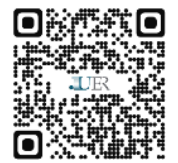

Article:

The Role of Architecture in the Identification of Obstacles and Spatial Solutions to Inclusive Education

Ayesha. M. Malik

Author(s):

Online Published: 2018

Article DOI:

Muhammad Yusuf Awan

https://doi.org/10.32350/uer.12.03
Memona Rashid

Iram Batool Alvi

Article QR Code:

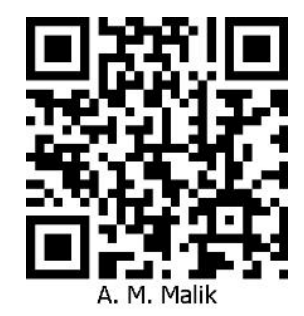

To cite this article: Malik, A. M., Rashid, M., Awan, M. Y., \& Alvi, I. B. (2018). The role of architecture in the identification of obstacles and spatial solutions to inclusive education. $U M T$ Education Review, 1(2), 39-58.

$\underline{\text { Crossref }}$

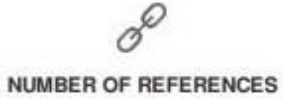

58

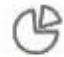

NUMBER OF FIGURES

07

$$
\text { 斑 }
$$

NUMBER OF TABLES

00

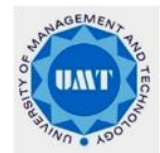

A publication of the

Department of Education, School of Social Sciences and Humanities, University of Management and Technology, Lahore, Pakistan. 


\title{
The Role of Architecture in the Identification of Obstacles and Spatial Solutions to Inclusive Education
}

\author{
Ayesha M. Malik ${ }^{1}$ \\ Memona Rashid ${ }^{2}$ \\ Muhammad Yusuf Awan ${ }^{3}$ \\ Iram Batool Alvi ${ }^{4}$
}

\begin{abstract}
Education is the basic right of every child. However, there are many barriers to education for children with special needs. These special needs are due to their physical or physiological make up and are the reason they often feel desolated, mostly due to the lack of educational facilities required to fulfil those needs that should be available for all. This conceptual paper attempts to outline the term 'inclusive education' in terms of the democratic principles established by the international community. The paper also attempts to discuss Pakistan's progress in adopting inclusive education by analyzing the current institutional framework of the education sector and infrastructure constraints in mainstream schools. Various case studies about educational centers in Pakistan's urban hubs have been analyzed also to learn more about the impediments in this regard. Moreover, data has been collected from 25 districts of Punjab to learn about the current status of public schools and to know whether or not they have been transformed into inclusive schools. Findings show that building design is a major barrier among other challenges. Building layout of an inclusive school has been presented as a model for making existing schools more inclusive for students with various disabilities, so that benefits of inclusion are drawn not only by the disabled but also by mainstream students.
\end{abstract}

Keywords: architectural solutions, educational obstacles, inclusive education, spatial layouts.

\footnotetext{
${ }^{1}$ Assistant Professor, School of Architecture and Planning, UMT, Lahore, Pakistan.

${ }^{2}$ Assistant Professor, School of Architecture and Planning, UMT, Lahore, Pakistan.

${ }^{3}$ Dean, School of Architecture and Planning, UMT, Lahore, Pakistan.

${ }^{4} \mathrm{Ph}$. D. Student, Special Education, University of Management and Technology, Lahore, Pakistan.

Corresponding Author: Ayesha M. Malik <ayesha.malik@umt.edu.pk>
}

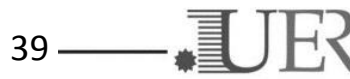




\section{Introduction}

Inclusive education deals with educating children with disabilities in mainstream schools instead of excluding them through a so-called system of 'special schools'. Several researchers and scholars have come up with several ideas related to inclusive education. Ainscow and associates have repeatedly stressed that the process of inclusion is targeted towards increasing the participation of children with 'special educational needs' and/or disabilities in the conventional education system, instead of segregating them (Ainscow, 1998; Booth \& Ainscow, 2002; Ainscow, Booth \& Dyson, 2006; Ainscow \& Sandill, 2010; Booth, Ainscow, Black-Hawkins, Vaughan \& Shaw, 2000). The whole concept is based on a democratic approach towards the education system and the needs of disabled students.

Strømstad (2003) has supported this approach by explaining that the concept of inclusion is about accepting diversity and striving together. It is not about bringing someone who has been previously kept out into an environment that doesn't conform to normal diversity (Armstrong, Armstrong \& Spandagou, 2011; Lindsay, 2003; Mittler, 2000). Merely being together is not always enough, rather every included member of staff and students must understand that their deeds and words have an effect on the feelings, selfimage and lives of other individuals (Ainscow, 2005; Armstrong, 2005; Vislie, 2003). UNESCO has also endorsed this democratic approach towards the education system and has stated that it demands a climate of tolerance and respect for nurturing a democratic culture (UNESCO, 2001). Such a culture based on democratic norms is essential for an inclusive education system.

Inclusion can also be defined as the strategy of addressing the needs of all students, rather than seeing a few students having "special" needs. It is a process which must assign all students due importance so that they can act as a complete fabric of human experience; enlarging the spectrum of inclusion from simply addressing the needs of children with special needs to challenging all exclusionary methods and norms in the education system (Allan, 2007; Armstrong, 2005; Christensen, 1992; Lindsay, 2003).

Thus, inclusion cements its place due to relevance for all those groups of learners which have been systematically excluded from mainstream education due to their being affected by issues such as neglect, war, poverty or social segregation. Similarly, Singh (2009) refers to inclusion as accepting children with disabilities and/or 'special educational needs' into mainstream schools instead of segregated schools. Booth (1998) defines inclusion as a process of minimizing exclusion and maximizing participation within schools by defeating all the impediments to learning for all. Scholars and practitioners following Booth further argue that we must stop segregating children into 'general' and 'special' categories in order to highlight actual differences among all children without drawing further differences among various groups 
of children (Armstrong, Armstrong \& Barton, 2016; Mittler, 2012; Slee, 2011).

Studies have shown that inclusive education is very much needed to facilitate children with varying educational needs from all divisions of society. The conventional education system needs several modifications to cater the individuals with special needs in Pakistan (Hameed, 2005; Hameed \& Fazil, 2012; Manzoor, 2015; Pasha, 2012). Many researchers have argued that the concept of inclusive education is not limited to students with disabilities but extends to all those students who lack the necessary access to educational facilities on an equal basis and are underprivileged due to societal differences (Ainscow \& Sandill, 2010; Armstrong, 2005; Armstrong et al., 2011). Inclusive schools handle the diverse needs of their students by adopting various methods of learning and ensuring high quality education through proper curricula, teaching methodologies and community partnerships.

\subsection{Inclusive Education in Pakistan}

During the last few decades, Pakistan has seen a surge in measures taken to promote policies and uplift facilities for disabled students. The development of policy for disabled persons started in the year 1985 and the National Policy for Persons with Disabilities was formulated in the year 2002. This policy comprehensively dealt with all the major topics of concerns and services related to disabled persons, especially students. It included aspects like medical care, education, employment, allocation of funds for various services, research and development, architectural changes in new and existing buildings, parks and other public spaces to fulfill the basic needs of disabled persons (Ministry of Women Development, Social Welfare \& Special Education, 2002). This policy was a major milestone in the history of special education in Pakistan. Provincial governments were engaged by the federal government for taking necessary measures and a separate Department of Special Education was created in the Punjab province. In every major city of the province, special education centers were built to educate students with various types of disabilities, such as visual and hearing impairments etc. Teachers were incentivized through greater salaries as compared with conventional schools. Various studies were also launched at the national level under the Directorate General of Special Education (DGSE) to ascertain the impact of these services and to uplift their quality.

However, all these efforts were based on the segregation of students in 'special' and 'ordinary' categories. Although ordinary schools are much more prevalent in all areas of the country, they lack the necessary infrastructure to accommodate students with special needs. On the other hand, schools for special education are present only in major cities and have a limited capacity but also have much greater facilities to educate disabled students. This has led to a policy dilemma; whether increase the budget available for specialized 
schools and increase their coverage to smaller cities or make ordinary schools more inclusive. Already some of the ordinary schools have been accommodating disabled students in areas where there are no special education centers. Following the rest of world, Pakistan has also witnessed a change in the approach towards students with special needs. Since disabled students are scattered widely all over the country, it is virtually impossible to develop special schools in every city. Due to the prevailing circumstances, policy makers have started accepting that a better approach would be to make conventional schools more inclusive by introducing some key changes. Moreover, the Federal Government of Pakistan is also obliged to end the discriminatory treatment of disabled persons, since it has ratified the UN Convention on the Rights of the Persons with Disabilities (UNCRPD). National Education Policy of Pakistan (2009) also pushes for children friendly inclusive education.

Not only school level education but higher education also demands inclusion. Pakistan's Higher Education Commission (HEC) has come up with a policy for disabled students studying in universities (HEC, n.d.). This policy is mandatory for every HEC recognized university. According to the policy, each university has to notify a Disabilities Committee which will oversee the provisioning of various services to students with special needs. These services include disability tutors, equal opportunities of admission, inclusive curriculum and assessment methods. Moreover, HEC has also formulated a building review committee to ensure that the Disability Code is actually implemented in the construction of freshly built infrastructure with the government's public spending budget. Also, under this policy, accessible accommodation facilities will have to be provisioned by every university authority, which includes separate wings with accessible bathrooms in large hostels etc. There have been numerous studies with regard to the prospects of inclusive education in major urban hubs of Pakistan. These studies have attempted to record the views of school teachers, parents, students and other stakeholders regarding the barriers to inclusive education in Pakistan. All such studies have emphasized the lack of facilities, basic infrastructure and teachers' abilities to accommodate inclusion.

Pasha (2012) conducted a detailed study on seventy-five schools within the Lahore city and interviewed nearly three-hundred teachers. The study found that conventional schooling system in Pakistan is currently underpowered to successfully implement inclusive education due to several challenges. These include lack of appropriate training for teaching and nonteaching staff, non-supportive admission policies for the promotion of inclusive education, lack of encouragement from parents and communities towards inclusion, and most of all, non-supportive school infrastructure for disabled students mainly due to the lack of necessary funds. The burden of 
these challenges is so menacing in some parts of the country that even envisaging inclusive education is out of the question. However, the study found some encouraging facts as well. Teachers in most of the schools are optimistic that if inclusive education is promoted in an appropriate manner, it can produce exceptional results for every category of students. Most of the teachers are positive about diversity and welcome the notion of collaboration between children with different types of learning needs. This positivity is a key ingredient for the success of inclusive education and government authorities can thrive on it.

Farooq (2012) studied thirty-four elementary schools of Lahore city and found teacher's role in ensuring inclusive learning extremely important. Teachers in conventional schools have no training to deal with disabled students and prefer to teach mainstream students only. Both teachers and parents of students in these schools lack appropriate awareness about the learning needs of disabled students and have negative psychological impressions about them. Satisfactory outcomes can only be achieved if positive attitudes are developed towards inclusive education which needs the involvement of the community, training of teachers and policy shift from segregated education towards inclusive education.

Behlol (2011) also conducted a study on twelve schools within the Islamabad city territory running under the Federal Directorate of Education. He also identified several key impediments in the path towards inclusive education. Most of these challenges are related to infrastructure shortcomings in these schools and lack of proper teacher training. Some social and disciplinary issues are also at play here such as the stigmatization of disabled students by peers which can lead to hooting and bullying. Most of the infrastructure constraints are due to inaccessible school buildings and nonavailability of transport system for disabled students. The environment of the majority of schools remains non-friendly towards students with special needs due to severe shortage of appropriate classrooms, playgrounds and accessible hygiene facilities. Teaching techniques do not conform to the modern concept of inclusive education and require a paradigm shift through learning aids and better assessment practices. Teacher attitude also requires realignment with concepts like diversity, democracy and collaboration. The study revealed that most of the teachers are less optimistic about inclusive learning since they assume that it will make their jobs tougher and disabled students will have to be educated at the cost of mainstream students. Support from parents also remains missing since for them 'inclusive education' is a totally unknown concept. Most of the studies quoted above have pointed towards infrastructure problems in school buildings. 


\section{Methods and Materials}

After the detailed review of the situation in international and Pakistani perspective, a short survey was planned to know the exact situation currently prevailing in Punjab. Teachers of public schools and social activists working with various non-government organizations (NGOs) were approached via email. Their contacts were obtained from the convener of International Conference on Inclusive Education (2017), organized by the University of Management and Technology, Lahore, Pakistan. Concerned persons in all 36 districts were approached, totaling about 150, via email and personal contact via WhatsApp. Only 70 persons responded from 25 districts to our call. The mean of respondents from each district was 2.23 and 4 was the mode; $70 \%$ respondents were male and $30 \%$ were female. The items were adapted from the extensive literature review of the topic. 46 items were included in the questionnaire developed on a dichotomous scale of YES and NO. The survey questionnaire is shared as Appendix A.

\section{Results}

The survey collected data from 25 districts of the Punjab province namely Pakpatan, Arifwala, Sahiwal, Okara, Chistian, Vehari, Multan, D.G. Khan, Rajanpur, Muzafargarh, Kasur, Lahore, Sheikhupura, Hafiz Abad, Nankana, Sargodha, Faisalabad, Gujranwala, Gujarat, Sialkot, Jehlum, Bhawalnagar, Bhawalpur, and Jehlum. All the data collected through questionnaires was carefully analyzed through SPSS software used for statistical analysis in social sciences' research.

The results confirmed that proper infrastructure according to international standards is missing in public schools in Punjab. Therefore, public schools in Punjab can't be easily converted into inclusive schools. Disagreement was higher than agreement in most of the statements such as 'school buildings are not designed to assist students with disabilities especially wheelchair users' and 'there is no access for them in classrooms and bathrooms'. Physical access for students with hearing impairment, low vision and partly sighted students is possible to some extent. Strong disagreement was expressed with the availability of facilities and proper infrastructure (40 statements out of 46) for people with disabilities (PWDs) according to international standards. Location maps and tactile and visual guidance of accessible toilets and emergency routes are also not considered. All these hint towards the formation of better design strategies for PWDs. 100\% disagreement was expressed in 19 cases while $100 \%$ agreement was expressed in only one case. In 40 out of 46 cases, disagreement with the provision of facilities according to international standards ranged from 52\%-100\% (See Appendix A for details).

Hence, it is inferred that the greatest impediment in the road to inclusiveness in public schools of Punjab is the lack of appropriate school 
infrastructure. So, the current researchers have focused on highlighting the architectural aspects of educational infrastructure by incorporating certain changes in public schools' space. By doing these small changes, mainstream schools can be transformed into inclusive ones. Such changes will not only benefit PWDs but general students as well; they will learn to live in a more collaborative and democratic environment heading towards an inclusive culture.

Following are some suggestions about the architectural and infrastructural design of purpose-built school buildings needed for inclusive education.

School architecture based on the concept of inclusion is not only modern but also has more utility. It doesn't rely completely on a single human sense (sight/vision); rather it is multi-sensory to overcome the deficiencies of people with special needs. Interior and exterior design is based on the use of all human senses creating sensory zones. Children with special needs feel comforted by these features and are able to perform better in their studies without getting segregated from the mainstream education.

\subsection{Architectural Design for Inclusive Schools: Universal Design Theory}

Inclusive schools demand inclusive architecture. The modern theory of "universal design" acts as the basis for inclusive architecture. Ronald Mace is credited with proposing this theory that architecture should be designed in a manner which maximizes its utility for different types of users (Wilkoff \& Abed, 1994). Instead of following the prevailing norms of treating disabled and other individuals with special needs as an anomaly, universal design promotes inclusion. Many scholars and researchers have argued to re-theorize public space (Carmona, 2015) and school is one of them; modifications in school space are needed in designing fields such as landscapes, architecture, and interior spaces etc. for PWDs (Imrie \& Hall, 2003; Page \& Thorsteinsson, 2018; Petrie, Devcich, \& Fitzgerald, 2018; Schinazi, Thrash \& Chebat, 2016). Following these propositions, multiple products should be designed to cater the needs of different categories of users (young, old, disabled etc).

Individual retrofitting is replaced by inclusive design features. For example, captioning of movies is not only helpful for people with hearing impairments but also helps general users in noisy settings like airports and train terminals. Similarly, curb cuts assist both individuals utilizing wheelchairs and skateboards. Globally used communication symbols, for example, restroom signs provide relief to persons with reading disabilities and non-English speaking users (Baglieri \& Shapiro, 2017; Imray \& Colley, 2017; McGuire, Scott \& Shaw, 2006). This is not limited to architecture and buildings but is also applicable to teaching methodologies being employed at inclusive schools (Barton \& Smith, 2015; Nightingale, Anderson, Onens, Fazil \& Davies, 2019). 


\subsection{Inclusive Architecture for Children with Cognitive Impairment}

3.2.1. ADHD and Down Syndrome. Children suffering from ADHD find it harder to control their reactions and pay attention to details. They show fidgety behavior and often interrupt others. Mostly, they have learning and cognitive impairments. Children with Autism Spectrum Disorder (ASD) are unable to appropriately interact and communicate with others. Their personal behavior remains disorderly. Down syndrome leads to delayed motor skills along with weakened communication and cognitive skills such as language and speech. Down syndrome is caused due to disorder in genetic alignments. People with this disorder mostly suffer from short term memory loss and have serious learning difficulties (Tufvesson \& Tufvesson, 2009; Brereton, Sitbon, Abdullah, Vanderberg \& Koplick, 2015).

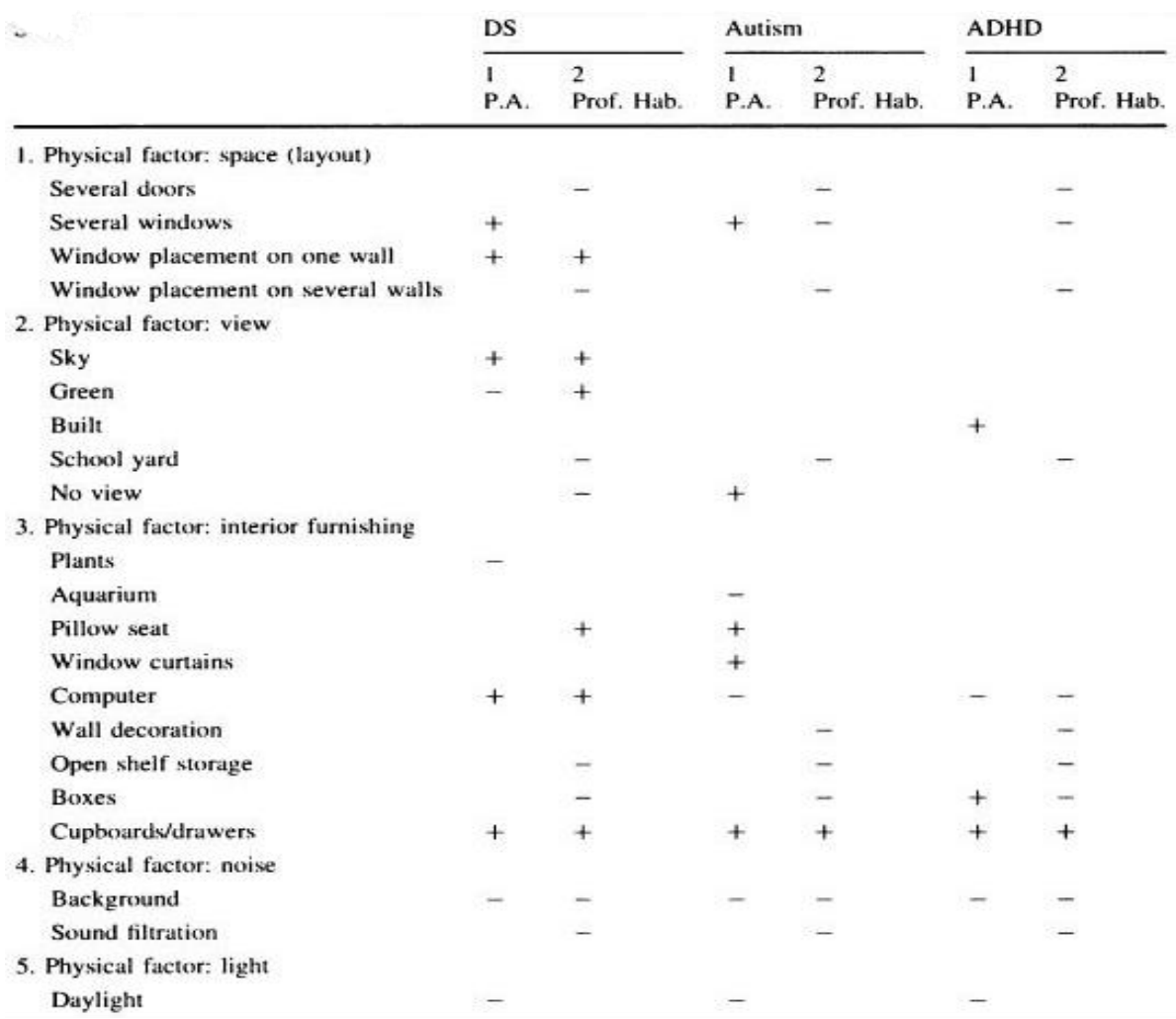

Figure 1. Results of studies by Tufvesson \& Tufvesson, (2009) indicating the effect of physical space on children with cognitive impairment

Children with these three medical conditions are extra sensitive to their surrounding environment. Difficulties in staying focused arise from the above mentioned learning and cognitive impairments, especially within an environment with multiple sensory inputs like emotional, visual and auditory influences. Two studies have been performed on the influences of various architectural features on students with these three disabilities and the results 
have been tabulated in the form of a table we have shared below. ' + ' sign indicates positive outcome while '-' sign indicates a negative outcome (Tufvesson \& Tufvesson, 2009). The physical factors included in this study are views through windows, room layout, noise and lighting. Such changes can make inclusion live again (Imray \& Colley, 2017).

3.2.2 Learning Space for Children with Autism Spectrum Disorder (ASD). Autistic individuals have different sensory alignments as they interpret surrounding architectural environment through sensory zoning instead of conventional functional zoning. Appropriate positioning of 'transitional zones' in the shape of gardens or sensory curriculum areas should be introduced in order to counter the effects of high sensory stimulus, as well as, other distractions (Gavaldá \& Qinyi, 2012; Martin, 2016; Mostafa, 2008). Subtle zoning arrangements make the transition more fluid helping to improve the navigational skills of autistic children by providing a sensory calibration. Buildings designed in such a manner improve the smoothness of transitions and protect users from getting overwhelmed with buzzing effects of lighting or sound. Interestingly, such a multi-sensory architectural setup appears pleasing to general students and other school building users as well promoting the much needed concept of inclusive education. McAllister (2010) invites to explore such ideas, whereas many other researchers emphasize co-designing with the autistic (Gaudion, Hall, Myerson \& Pellicano, 2015)

3.2.3. Space for Children with Visual and Hearing Impairments. There are degrees of visual impairments and individuals with a low vision rely on contrasting colors to detect spatial changes. However, individuals with complete vision loss have to rely on their other senses (touch, smell and hearing) to detect such changes. Inclusive school buildings should have sufficient lighting from different controllable sources to reduce the amount of glare which can seriously affect the visual capabilities of children with visual impairments. Stair edges must visually contrast with the flooring and the surface treatment of flooring with dark stripes across the direction of travel can aid people with low vision (Walden, 2008; Avsatthi, 2016; Knoop, 2013).

Highly polished surfaces can create problems and create obscure changes leading to tipping problems. Lighting should be placed in a manner which makes signage prominent. Circulation spaces such as corridors and lobbies should either be clear from obstructions and hazardous projections like furniture and columns or they must show ample color contrast with the surroundings. 


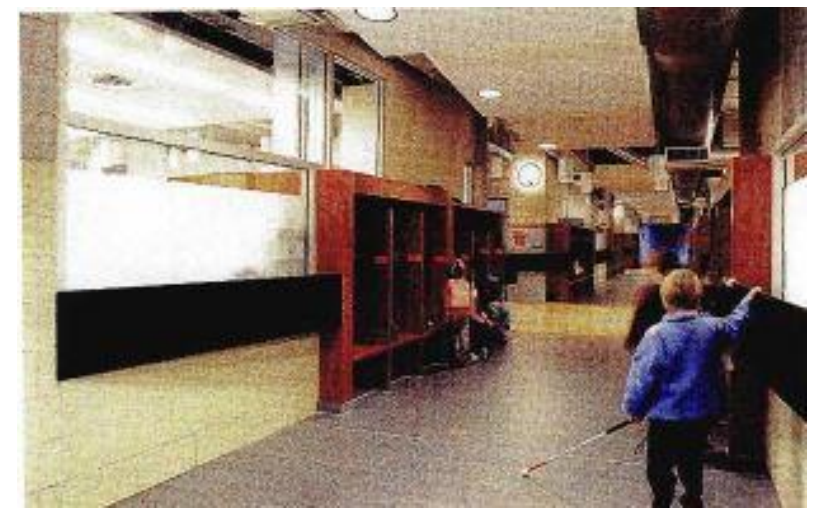

Figure 2. Supporting walls for the visually impaired (source: knoop, 2013)

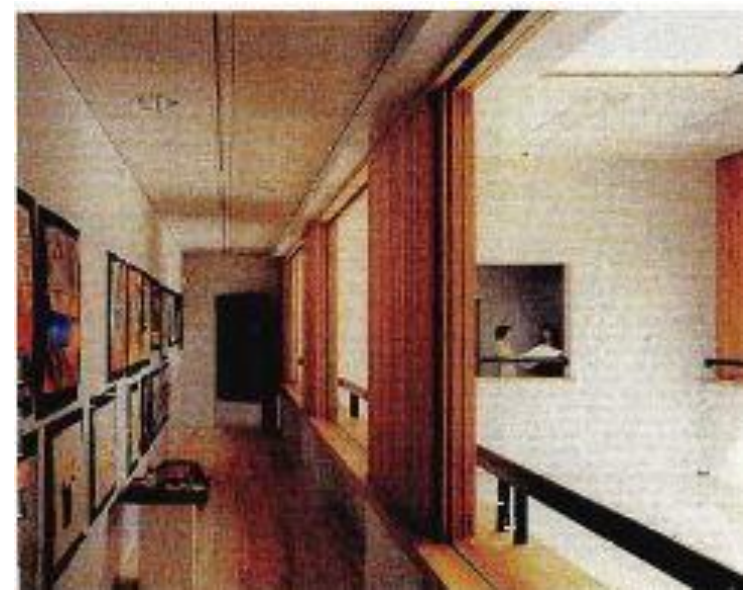

Figure 3. Dark and light contrasts created for the Visually Impaired

Winding pathways should be avoided and different surface material should be used for different pathways as it creates a sense of spatial uniqueness of each zone. A healthy mix of ramps and stairs is helpful for visually impaired persons but they should be visually contrasting. Glass doors should be used very intelligently. Doors made of other materials should also contrast with the surrounding environment. Outdoor landscape should be designed also using these measures, where pathways should be made to appear distinctive using unique materials and landscape arrangements.

Since hearing impaired persons utilize sign language based on the movements of hands to convey signal, they have greater problems in walking while talking. Automatic doors with movement sensors help them to multitask like other humans (Barley, 2013). Building for hearing impaired persons is designed based on the concept of 'visual connectivity' (Johnson, 2014; Tsymbal, 2010). One has to understand that hearing impaired individuals rely more on their eyes for finding their way. They interact with each other through sign language using their hands. Direct visual contact is necessary in this 
condition and the building fabric has to be altered in a manner which improves visual connectivity.

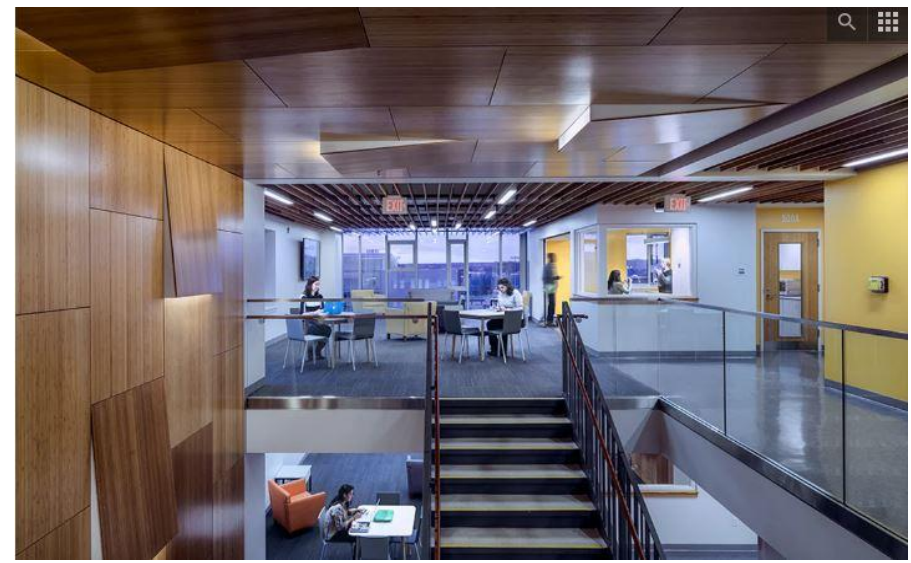

Figure 4. School designed for hearing impaired with transparent railings and corners (Source:Barley, 2013)

Transparency is one technique which can help the most. Transparent railings, transparent corners and even transparent doors assist the hearing impaired in using school buildings. Multipurpose areas having sweeping views in an open environment are also good for guidance and improving traffic circulation (Tsymbal, 2010).

3.2.4. Building Layout for an Inclusive School. A building layout for inclusive school has been discussed by Turkish researchers (Durak \& Erkiliç, 2012). This model can be successfully adopted across Pakistan to promote the principles of collaboration and harmony. Every school building should have separate wings for general and special education. This can help in protecting disabled students from stigmatization and other disciplinary issues. General education classrooms are designed to cater general and disabled students (depending on their disability). Desks can be arranged in U-shape for group study and students using wheelchairs can be allowed to sit at the front. There are also separate resource rooms for one-to-one guidance of needy students.

Special education classrooms are designed in a way that teachers can work with every student in an individual manner. ICT desk is also available at the rear. Special education classrooms have adjacent resource rooms where all facilities for personal hygiene and study are available. 


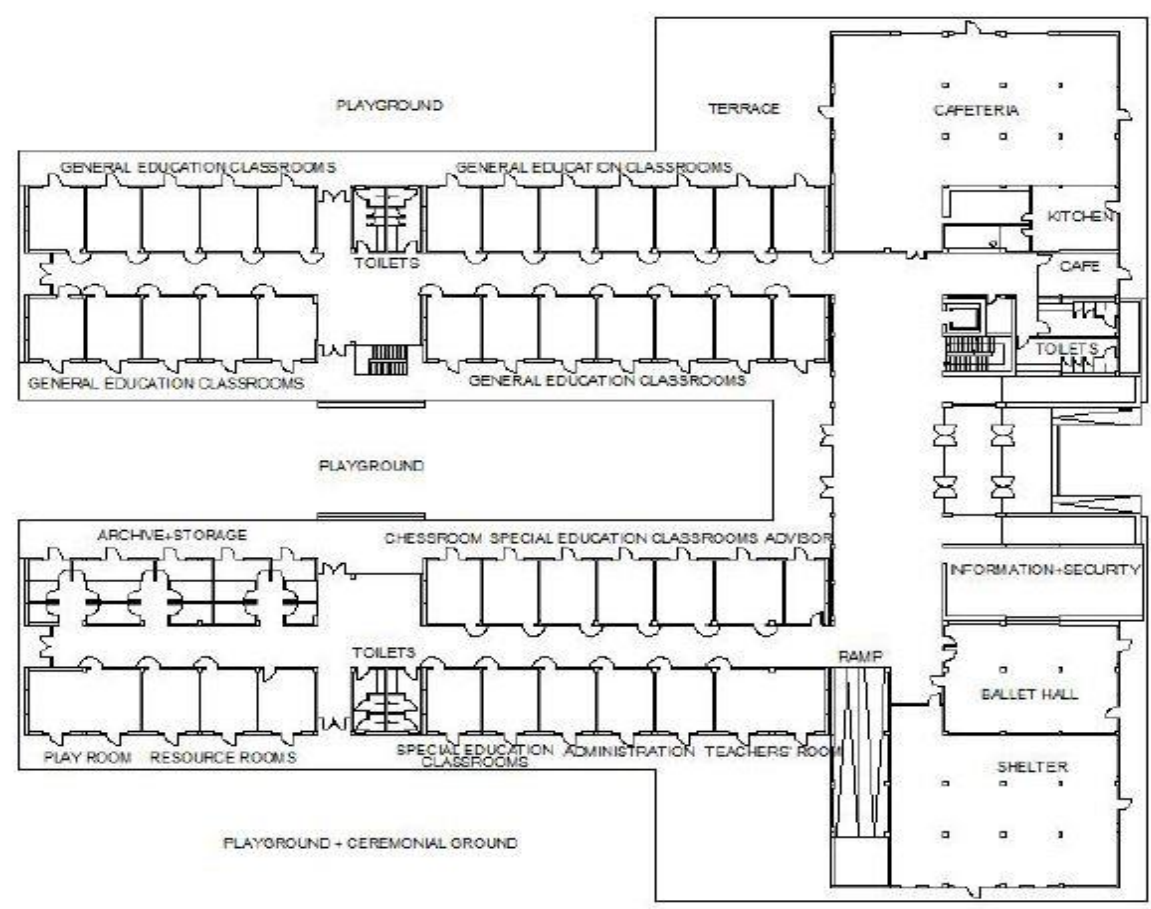

Figure 5. Layout design of an inclusive school

These rooms are handy for students with cognitive disabilities. Multipurpose cupboards assist a great deal in storing student work and other teaching material and must be present in every classroom (Durak \& Erkiliç, 2012). Bathrooms in inclusive schools must also be accessible through wheelchairs and be equipped with panic alarms and other necessary items to make self-care easier for disabled students.

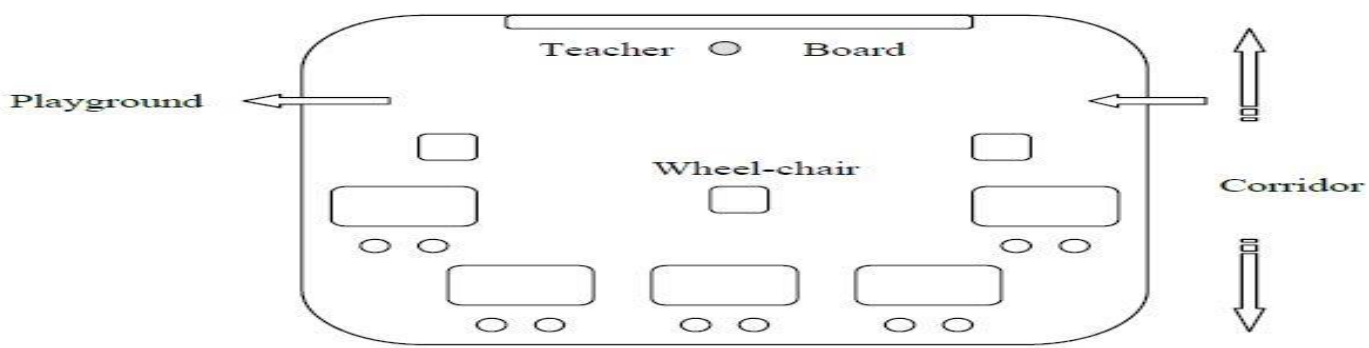




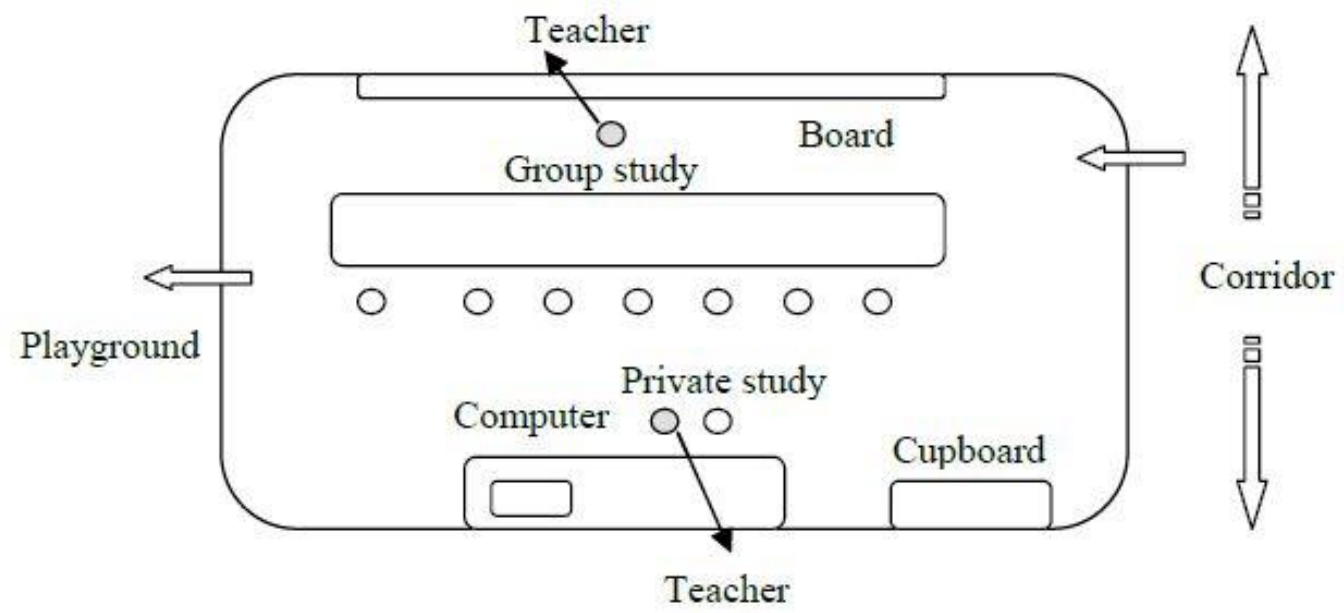

Figure 7 Special Education Classroom Layout

\subsection{Epilogue}

Inclusive education is a much needed concept in Pakistan and policy makers here have slowly but surely started accepting its importance for the education sector. It is concluded here on the basis of survey data that public schools in Punjab are not equipped with proper infrastructure and facilities according to international standards. Therefore, schools are not transforming into inclusive schools in spite of government showing interest. Public willingness can be created with slight modifications in the infrastructure. Cost can be managed with the help of welfare agencies and by selling the space for promotion to multinational and local companies. It will further invoke public interest and participation as well as allow different corporations to indulge in corporate social responsibility (CSR) activities. It is strongly recommended to the Punjab government that they may take this initiative to promote inclusion by increasing physical access to schools conforming to international standards.

\section{References}

Ainscow, M. (2005). Developing inclusive education systems: What are the levers for change? Journal of Educational Change, 6(2), 109-124.

Ainscow, M., Booth, T., \& Dyson, A. (2006). Improving schools, developing inclusion. London: Routledge,

Ainscow, M., \& Sandill, A. (2010). Developing inclusive education systems: The role of organizational cultures and leadership. International Journal of Inclusive Education, 14(4), 401-416, 
Allan, J. (2007). Rethinking inclusive education: The philosophers of difference in practice (vol. 5). Dordrecht: Springer Science \& Business Media.

Armstrong, D. (2005). Reinventing 'inclusion': New labour and the cultural politics of special education. Oxford Review of Education, 31(1), 135151.

Armstrong, D. Armstrong, A. C., \& Spandagou, I. (2011). Inclusion: by choice or by chance? International Journal of Inclusive Education, 15(1), 2939.

Armstrong, F., Armstrong, D., \& Barton, L. (2016). Inclusive education: Policy, contexts and comparative perspectives. London: Routledge.

Author (NA). (2002). National policy for persons with disabilities Pakistan. Islamabad: Ministry of Women Development, Social Welfare \& Special Education.

Avsatthi, B. (2016). Deaf space: Architectural design support should adapt to this emerging diversity in architecture. Retrieved on 23-07-17 from https://archinect.com/HCADDS/release/deafspace-architecturaldesign-support-should-adapt-to-this-emerging-diversity-inarchitecture

Baglieri, S., \& Shapiro, A. (2017). Disability studies and the inclusive classroom. New York, NY: Taylor \& Francis.

Barley, L. (2013). Deaf space: Empathetic design provides architectural solutions for the hearing impaired. Retrieved on 23-07-17 from https://architizer.com/blog/deaf-space/

Barton, E. E., \& Smith, B. J. (2015). Advancing high-quality preschool inclusion: A discussion and recommendations for the field. Topics in Early Childhood Special Education, 35(2), 69-78.

Behlol, M. G. (2011). Inclusive education: Preparation of teachers, challenges in classroom and future prospects. Pakistan Journal of Education, 28(2), 63-73.

Booth, T., \& Ainscow, M. (Eds.). (1998). From them to us: An international study of inclusion in education. London: Routledge.

Booth, T., Ainscow, M., Black-Hawkins, K., Vaughan, M., \& Shaw, L. (2000). Index for inclusion: Developing learning and participation in schools. Bristol: Centre for Studies on Inclusive Education.

Brereton, M., Sitbon, L., Abdullah, M. H. L., Vanderberg, M., \& Koplick, S. (2015). Design after design to bridge between people living with cognitive or sensory impairments, their friends and proxies. CoDesign, 11(1), 4-20.

Carmona, M. (2015). Re-theorising contemporary public space: A new narrative and a new normative. Journal of Urbanism: International Research on Place making and Urban Sustainability, 8(4), 373-405. 
Christensen, C.A. (1992). Social justice and the construction of disability in schools. Australian Association of Special Education Newsletter, 3, 68.

Durak, S., \& Erkiliç, M. (2012). Inclusive education environments from the teachers' perspective: An inquiry in a Turkish primary school. Children, Youth and Environments, 22(1), 304-313.

Farooq, M.S. (2012). Problems faced by students with special needs in ordinary Pakistani schools. Journal of Quality and Technology Management, 8(1), 13-27.

Gaudion, K., Hall, A., Myerson, J., \& Pellicano, L. (2015). A designer's approach: How can autistic adults with learning disabilities be involved in the design process? CoDesign, 11(1), 49-69.

Gavaldá, J. M. S., \& Qinyi, T. (2012). Improving the process of inclusive education in children with ASD in mainstream schools. ProcediaSocial and Behavioral Sciences, 46, 4072-4076.

Hameed, A. (2005). Removing barriers to inclusive education in Pakistan. Proceedings of the Second Regional Seminar on Childhood Disability. Dhaka, Bangladesh: BPF.

Hameed, A., \& Fazil, H. (2012).Implications of UN convention on the rights of persons with disabilities 2007 for education policy in Pakistan. EDULEARN11 Proceedings (pp. 584-589). Barcelona: IATED.

Higher Education Commission (HEC). (n.d.). Policy for students with disabilities for higher learning institutes in Pakistan. Islamabad: Author. Retrieved on 23-07-17 from http://hec.gov.pk/english/services/universities/Pages/Policy.aspx

Imray, P., \& Colley, A. (2017). Inclusion is dead: Long live inclusion. London: Routledge.

Imrie, R., \& Hall, P. (2003). Inclusive design: Designing and developing accessible environments. London: Taylor \& Francis

Johnson, C. A. (2014). Articulation of deaf and hearing spaces using deaf space design guidelines: A community based participatory research with the Albuquerque sign language academy (Unpublished Master's thesis). The University of New Mexico Albuquerque, New Mexico. Retrieved on 24-09-17 from http://digitalrepository.unm.edu/arch_etds/18

Knoop, S. L. (2013). Architecture for low vision: Site, building and interior design. Paper presented at the national institute of building sciences low vision design committee symposium. Retrieved 24-09-17 from https://cdn.ymaws.com/www.nibs.org/resource/resmgr/LVDC/lvdc2013 _paper_knoop.pdf

Lindsay, G. (2003). Inclusive education: A critical perspective. British Journal of Special Education, 30(1), 3-12. 
Manzoor, A. (2015). Analysis of being unreached and its compatibility with available educational provisions (Unpublished MPhil Thesis). Allama Iqbal Open University, Islamabad, Pakistan.

Martin, C. S. (2016). Exploring the impact of the design of the physical classroom environment on young children with autism spectrum disorder (ASD).Journal of Research in Special Educational Needs, 16(4), 280-298.

McAllister, K. (2010). The ASD friendly classroom-design complexity, challenge and characteristics. Paper presented at the Design Research Society Conference. Retrieved on 24-09-17 from http://www.designresearchsociety.org/docsprocs/DRS2010/PDF/084. pdf.

McGuire, J.M., Scott, S.S., \& Shaw, S.F. (2006). Universal design and its applications in educational environments. Remedial and Special Education, 27(3), 166-174.

Mittler, P. (2000). Working towards inclusive education. London: David Fulton.

Mostafa, M. (2008). An architecture for Autism: Concepts of design intervention for the autistic user. International Journal of Architectural Research, 2(1), 189-211.

Nightingale, K. P., Anderson, V., Onens, S., Fazil, Q., \& Davies, H. (2019). Developing the inclusive curriculum: Is supplementary lecture recording an effective approach in supporting students with specific learning difficulties (SpLDs)? Computers \& Education, 130, 13-25.

Page, T., \& Thorsteinsson, G. (2018). An inclusive design study of wheelchair users in the built environment. Journal of Engineering, 6(1), 1-18.

Pasha, S. (2012). Readiness of urban primary schools for inclusive education in Pakistan. Journal of Research and Reflections in Education, 6(2), 113-128.

Petrie, K., Devcich, J., \& Fitzgerald, H. (2018). Working towards inclusive physical education in a primary school: 'Some days I just don't get it right'. Physical Education and Sport Pedagogy, 23(4), 345-357.

Schinazi, V. R., Thrash, T., \& Chebat, D. R. (2016).Spatial navigation by congenitally blind individuals. Wiley Interdisciplinary Reviews: Cognitive Science, 7(1), 37-58.

Strømstad, M. (2003). They believe that they participate ...but: Democracy and inclusion in Norwegian schools. In J. Allan (Ed.), Inclusion, participation and democracy: What is the purpose? (pp. 33-47). Dordrecht: Kluwer.

Slee, R. (2011). The irregular school. London: Routledge.

Tsymbal, K.A. (2010). Deaf space and the visual world-buildings that speak: An elementary school for the deaf (Unpublished Master's thesis). University of Maryland, USA. 
Tufvesson, C., \& Tufvesson, J. (2009).The building process as a tool towards an all-inclusive school: A Swedish example focusing on children with defined concentration difficulties such as ADHD, Autism and Down's syndrome. Journal of Housing and the Built Environment, 24(1), 4766.

UNESCO. (2001). Dakar framework for action: Expanded commentary. Retrieved on 08-08-2017 from http://www.unesco.org/education/efa

Vislie, L. (2003). From integration to inclusion: Focusing global trends and changes in the Western European societies. European Journal of Special Needs Education, 18(1), 17-35.

Walden, K. (2008). Architecture for the visually impaired: Design of a society for the blind (Unpublished Master's thesis). University of KwaZuluNatal, Durban, South Africa

Wilkoff, W. L., \& Abed, L.W. (1994). Practicing universal design: An interpretation of the ADA. New York: Van Nostrand Reinhold. 


\section{Appendix A}

\begin{tabular}{|c|c|c|c|}
\hline $\begin{array}{l}\text { Sr. } \\
\text { No }\end{array}$ & Items & $\begin{array}{c}\text { Yes } \\
\%\end{array}$ & $\begin{array}{c}\text { No } \\
\%\end{array}$ \\
\hline 1 & $\begin{array}{l}\text { Have proper infrastructure according to } \\
\text { international standards }\end{array}$ & 0 & 100 \\
\hline 2 & Students can easily enter the school & 60 & 40 \\
\hline 3 & $\begin{array}{l}\text { School building is designed to assist students } \\
\text { with disabilities }\end{array}$ & 0 & 100 \\
\hline 4 & $\begin{array}{l}\text { The schools can easily be converted into } \\
\text { inclusive schools accommodating students with } \\
\text { special needs }\end{array}$ & 16 & 84 \\
\hline 5 & There is a ramp, preferably at the main entrance. & 48 & 52 \\
\hline 6 & $\begin{array}{l}\text { Accessible spaces, features and facilities marked } \\
\text { with the respective international symbols. }\end{array}$ & 0 & 100 \\
\hline 7 & $\begin{array}{l}\text { Directional signs to guide people with } \\
\text { disabilities are provided to assist them in } \\
\text { reaching their desired locations easily. }\end{array}$ & 0 & 100 \\
\hline 8 & $\begin{array}{l}\text { Height of signage placed is neither too high or } \\
\text { too low }\end{array}$ & 0 & 100 \\
\hline 9 & $\begin{array}{l}\text { Tactile information (which can be explored with } \\
\text { touch) is added. }\end{array}$ & 0 & 100 \\
\hline 10 & $\begin{array}{l}\text { Letter size is proportionate to the reading } \\
\text { distance }\end{array}$ & 20 & 80 \\
\hline 11 & $\begin{array}{l}\text { Contrasting colors are used in all signs and } \\
\text { notices }\end{array}$ & 20 & 80 \\
\hline 12 & $\begin{array}{l}\text { Obstructions or hazardous areas are provided } \\
\text { with tactile marking }\end{array}$ & 0 & 100 \\
\hline 13 & $\begin{array}{l}\text { Corridors are wide enough that visually } \\
\text { impaired or physically disabled students can } \\
\text { move easily }\end{array}$ & 44 & 56 \\
\hline 14 & $\begin{array}{l}\text { Obstructions and features that limit the width of } \\
\text { corridors are removed }\end{array}$ & 44 & 56 \\
\hline 15 & $\begin{array}{l}\text { If widening of corridors is not feasible, passing } \\
\text { areas are located at regular intervals }\end{array}$ & 64 & 36 \\
\hline 16 & Holes and uneven areas are repaired & 64 & 36 \\
\hline 17 & Floor surfaces are non-slippery and even & 70 & 30 \\
\hline 18 & Fastening of carpets are secure & 32 & 68 \\
\hline 19 & Visual and tactile guiding strips are provided & 0 & 100 \\
\hline
\end{tabular}


20 Visual and tactile marking are provided to

$0 \quad 100$ indicate the location of obstructions or changes of direction

21 Doors are wide enough and can be easily managed via hinge/block to keep it wide open for a while.

22 There are no heavy hard to open swinging doors in the building

23 Lever-type door handles are used in the building

24 Automatic doors are available at entrance to library and laboratory

25 Color of doors or door frames are contrasted with the adjoining walls

26 A lift/ramp is provided inside the building to go to upper stories

27 An alternative accessible route is provided

28 Handrails are placed next to stairs and ramps

$44 \quad 56$

$28 \quad 72$

29 Tactile marking strips at the top and bottom of stairs and ramps are provided in a color that contrasts with the surrounding floor

30 Adequate signage are added in the whole building

31 Sufficient lighting from different controllable $\quad 40 \quad 60$ sources is provided

32 Lighting is placed in a manner which makes signage prominent

$\begin{array}{llll}33 & \text { Glass doors are used in a way that they do don't } & 12 & 88\end{array}$ become a hazard

34 Transparent railings, transparent corners and even transparent doors assist hearing impaired while they are using school buildings are available

35 Multi-purpose cupboards assist a great deal in storing student works and other teaching material and are present in every classroom

36 Seating facilities are provided at the distance of $48 \quad 52$ every 200 meters at the least

37 Rearranging the layout of seats is allowed adjoining space of at least 1.20 meters next to benches and seats

38 Provision of replacing or modifying seats and $44 \quad 56$ tables that are too high or too low is present 


\begin{tabular}{|c|c|c|c|}
\hline 39 & Height of drinking fountains is approachable & 60 & 40 \\
\hline 40 & A double-tiered fountain is installed & 0 & 100 \\
\hline 41 & $\begin{array}{l}\text { Bathrooms are accessible through wheelchairs } \\
\text { with panic alarms and other necessary items to } \\
\text { make self-care easier for disabled students }\end{array}$ & 0 & 100 \\
\hline 42 & $\begin{array}{l}\text { For girls and boys feasibility of bathrooms is } \\
\text { separate }\end{array}$ & 76 & 24 \\
\hline 43 & Adequate grab bars in bathrooms are included & 0 & 100 \\
\hline 44 & $\begin{array}{l}\text { Location of accessible toilet is indicated with } \\
\text { the international symbol }\end{array}$ & 0 & 100 \\
\hline 45 & $\begin{array}{l}\text { Tactile and visual guidance is provided along } \\
\text { emergency routes }\end{array}$ & 0 & 100 \\
\hline 46 & $\begin{array}{l}\text { Audible alarm signals are provide for } \\
\text { emergency }\end{array}$ & 0 & 100 \\
\hline
\end{tabular}

